\title{
Synthesis and Characterization of a New Five and Six Membered Selenoheterocyclic Compounds Homologues of Ebselen
}

\author{
Mouslim Messali, ${ }^{1}$ Mostafa Abboudi, ${ }^{1}$ Mohamed R. Aouad, ${ }^{1}$ Nadjet Rezki, ${ }^{1}$ \\ and Léon E. Christiaens ${ }^{2}$ \\ ${ }^{1}$ Department of Chemistry, Taibah University, P.O. Box 30002, Madinah, Saudi Arabia
${ }^{2}$ Services Généraux (Faculté des Sciences) Relations Académiques et Scientifiques (Sciences), University of Liege,
allée de la Chimie 3, 4000 Liège 1, Belgium
}

Correspondence should be addressed to Mouslim Messali, mouslim@mail.be

Received 8 October 2011; Revised 18 December 2011; Accepted 27 December 2011

Academic Editor: Kirpal Bisht

Copyright ( $) 2011$ Mouslim Messali et al. This is an open access article distributed under the Creative Commons Attribution License, which permits unrestricted use, distribution, and reproduction in any medium, provided the original work is properly cited.

The discovery of the antioxidant activity of selenoenzyme glutathione peroxidase (GPx) has attracted growing attention in the biochemistry of selenium. Among molecules which mimic the structure of the active site of the enzyme, $\mathrm{N}$-phenyl-1,2benzisoselenazolin-3-one 1, Ebselen, exhibited useful anti-inflammatory properties. It has been extensively investigated and has undergone clinical trials as an anti-inflammatory agent. Unfortunately, Ebselen exhibits relatively poor catalytic activity, prompting attempts to design more efficacious GPx mimetics that would retain his low toxicity while manifesting improved catalytic properties. In this context, novel 1,2-benzoselenazine and 1,2-benzoselenazols, which are five and six membered homologues of Ebselen were synthesized and characterized. One structure has been proven by single crystal X-ray crystallography.

\section{Introduction}

The discovery of selenium as selenocysteine in the active site of the selenoenzyme glutathione peroxidase (GPx) has attracted growing attention in the biochemistry of selenium $[1,2]$. The selenoenzyme acts as an antioxidant and catalyzes the reduction of harmful peroxides by glutathione, thus protecting lipid membranes against oxidative damage [3-9]. The enzyme catalytic site includes a selenocysteine residue in which the selenium undergoes a redox cycle involving the selenol (Enz-SeH) as the active form that reduces hydroperoxides and organic peroxides and the catalytic cycle is shown in Scheme 1. Thus, the selenol (EnzSeH) is first oxidized by the peroxide to the corresponding selenic acid (EnzSeOH), which reacts with GSH to afford a selenenyl sulfide intermediate (EnzSeSG). The latter undergoes further reaction with GSH, thereby regenerating the original selenol and producing oxidized glutathione (GSSG) as a byproduct [10-13].

Among molecules which mimic the structure of the active site of the enzyme, $\mathrm{N}$-phenyl-1,2-benzisoselenazolin3-one 1, Ebselen (PZ51), exhibited useful anti-inflammatory properties [14, 15]. On the other hand, Ebselen contains a selenic moiety stabilized by intramolecular cyclisation in a cyclic $\mathrm{N}$-aroyl selenamide and does not release selenium, as demonstrated by a ${ }^{75} \mathrm{Se}$-labeling study, which result in its relatively nontoxic properties $[16,17]$. The discovery of its anti-inflammatory and glutathione-peroxidase (GPx)like activity has initiated numerous biochemical and pharmacological investigations as well as clinical trials as an antioxidant [18-21]. Similarly a study of the mechanism of the (GPx)-like activity of Ebselen has shown the formation in a catalytic cycle of various intermediates constituting different oxidation levels of the selenium atom $[22,23]$.

Several structural modifications of Ebselen including substituent effect and isosteric replacement have been proposed $[24,25]$. For instance, diselenides and non-benzocondensed isoselenazolidinone ring have been reported in the literature $[26,27]$.

Although it has attractive anti-inflammatory activity and low toxicity, Ebselen exhibits relatively poor catalytic activity, prompting attempts to design more efficacious GPx mimetics that would retain his low toxicity while manifesting improved catalytic properties. Hence, the design, synthesis, 


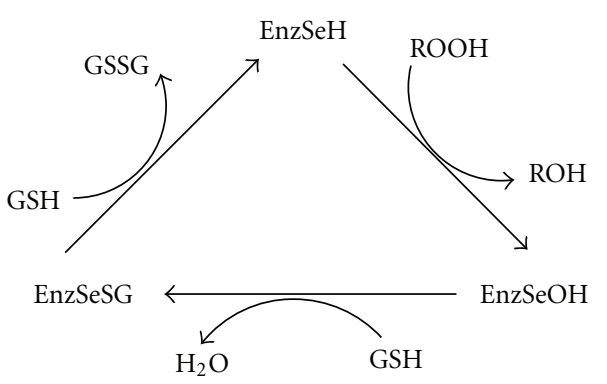

EnzSeH = glutathione peroxidase

$\mathrm{GSH}=$ glutathione

Scheme 1: Catalytic cycle of glutathione peroxidase (GPx).

and evaluation of small-molecule selenium compounds that mimic the biological activity of GPx have been investigated by several groups, and selected examples 2 [28], 3 [29], 4 [30], and 5 [31] are presented in Scheme 2. Various diaryl diselenides [32-38] and certain types of tellurium compounds as well as dendrimeric and cyclodextrin-derived organochalcogen catalysts that emulate GPx have also been reported [39-46].

In the same context, our group focused on synthesizing new selenoheterocyclic compounds. The new heterocycles should preserve the Se- $\mathrm{C}_{\text {aromatic }}$ bond to avoid the release of Se atoms and maintain the low toxicity of Ebselen. Secondly, the Se-N bond responsible for the GPx-like activity is retained.

\section{Results and Discussion}

The multistep synthesis of the novel benzoselenazine $\mathbf{1 0}$ is represented in Scheme 3. The starting molecule was $o$ chlorobenzonitrile $\mathbf{6}$, which was easily transformed into ketone 7 by reaction with Grignard reagent. The incorporation of selenium was carried out by treatment of ketone 7 with methaneselenol in the presence of potassium carbonate yielding $\mathbf{8}$ in good yield. The oximination of selenide 8 was carried out using $\left(\mathrm{n}-\mathrm{BuNO} \mathrm{NO}_{2}, \mathrm{HCl}\right)$ and 2ethoxyethanol as solvent [47]. Oxime 9 was cyclized into the novel heterocycle $4 H$-benzo-1,2-selenazin-4-one 10 via Se-demethylation using trimethylsilyl polyphosphate (PPSE) [48].

The synthesis of the new selenoheterocycle 14 required the use of diketone 12, which was obtained by oxidation of ketone 11 using $\mathrm{SeO}_{2}$ as an oxidizing agent. The incorporation of selenium was carried out by treatment of diketone $\mathbf{1 2}$ with methaneselenol in the presence of potassium carbonate yielding 13. The addition of 2 equivalents of bromine to a saturated solution of diketone $\mathbf{1 3}$ produced a yellow-orange precipitate. This precipitate, which is a result of quaternization of selenium by bromine, was treated by ammonia and purified to produce compound $\mathbf{1 4}$, as determined by different spectroscopic techniques.

In order to further prove the structure of compound 14, we attempted to independently synthesize the same compound starting from compound $\mathbf{1 1}$ according to the reactions outlined in Scheme 4. Thus, compound 14 was obtained by oxidation of novel heterocycle 16 , which in turn was prepared by bromination of ketone 15 followed by treatment with ammonia (Scheme 4).

In the same context, we describe a new strategy for the synthesis of a new heterocycle $\mathbf{2 0}$ analogue of Ebselen (Scheme 5).

2-Bromo-3-nitrobenzoic acid $\mathbf{1 7}$ was transformed via two steps to the hydrazide $\mathbf{1 8}$ and the selenium was incorporated as cited previously to give the selenide 19. The treatment of 2-methylseleno-3-nitro-3'-N-phenylbenzohydrazide with excess of bromine produced a yellow-orange precipitate. It allowed unambiguous identification of the molecular formula of the compound 20 (Figure 1). The crystal data structure refinement for compound 20 has been reported previously [49].

\section{Conclusion}

In order to evaluate their glutathione peroxidase-like activity, the synthesis of four novel heterocyclic compounds has been achieved. Namely, synthesis of 1,2-benzoselenazine4-one derivative 10 which is six membered homologue of Ebselen PZ51 and three 1,2-selenazols 14, 16 and 20. The new compounds were fully characterized and one structure of them has been proven by single crystal X-ray crystallography.

\section{Experimental}

4.1. Synthesis of 1-(2-(Methylselanyl)phenyl)-3-phenylpropan-1-one (8). To a mixture of methaneselenol (1.2 mmol), $\mathrm{K}_{2} \mathrm{CO}_{3}(2 \mathrm{mmol})$ and DMF $(40 \mathrm{~mL})$, ketone 7 and $(1 \mathrm{mmol})$ was added with stirring for a period of 30 minutes at $10^{\circ} \mathrm{C}$. The mixture was refluxed under stirring for $6 \mathrm{~h}$. After cooling, the mixture was washed with $(2 \times 10 \mathrm{~mL})$ of water, extracted $(3 \times 20 \mathrm{~mL})$ with toluene and dried over $\mathrm{MgSO}_{4}$. After evaporation of the solvent, the obtained residue was purified by column chromatography over silica gel using (toluene-acetone 95:5) as eluent to provide compound 8 as yellow oil, yield $68 \%$, IR $(\mathrm{NaCl}) v_{\max } 1664 \mathrm{~cm}^{-1}(\mathrm{C}=\mathrm{O}),{ }^{1} \mathrm{H}$ $\operatorname{NMR}\left(400 \mathrm{MHz}, \mathrm{CDCl}_{3}\right): \delta_{\mathrm{H}} 2.21(\mathrm{~s}, 3 \mathrm{H}), 3.15(\mathrm{t}, 2 \mathrm{H}), 3.29$ $(\mathrm{t}, 2 \mathrm{H}), 7.21-7.91(\mathrm{~m}, 9 \mathrm{H}) ;{ }^{13} \mathrm{C} \mathrm{NMR}\left(100 \mathrm{MHz}, \mathrm{CDCl}_{3}\right): \delta_{\mathrm{C}}$ 7.2 $\left(\mathrm{CH}_{3}\right), 31.0\left(\mathrm{CH}_{2}\right), 41.7\left(\mathrm{CH}_{2}\right), 124.9-142.1(\mathrm{C}$ arom $)$, $199.8(\mathrm{C}=\mathrm{O})$, GCMS: $\mathrm{m} / z$ of $>10 \%$ intensity $304\left(\mathrm{M}^{+}\right), 289$, 199.

4.2. Synthesis of 2-(Hydroxyimino)-1-(2-(methylselanyl)phenyl)-3-phenylpropan-1-one (9). To a solution of ketone 8 $(1 \mathrm{mmol})$ in ethoxyethanol $(20 \mathrm{~mL})$, concentrated $\mathrm{HCl}$ $(3 \mathrm{~mL})$ and $\mathrm{n}-\mathrm{BuNO}_{2}(1.2 \mathrm{mmol})$ were added with stirring at $0^{\circ} \mathrm{C}$. The mixture was stirred for overnight at room temperature and then washed with $30 \mathrm{~mL}$ of dichloromethane. The organic layer was washed with a solution of $\mathrm{NaOH}(1 \mathrm{M})(2$ $\times 10 \mathrm{~mL}$ ) and dried over $\mathrm{MgSO}_{4}$. After evaporation of the solvent, the obtained residue was purified by column chromatography over silica gel using (toluene-acetone $65: 35$ ) to provide compound 9 as yellow solid, yield $61 \%$, Mp 132$133^{\circ} \mathrm{C}$, IR $(\mathrm{KBr}) v_{\max } 3336 \mathrm{~cm}^{-1}(\mathrm{OH}), 1650 \mathrm{~cm}^{-1}(\mathrm{C}=\mathrm{O})$, 
<smiles></smiles>

1

Ebselen (PZ51)<smiles>[R]N1[Ge]c2ccccc2C([R])([R])C1=O</smiles>

2<smiles>[R]N1[Se]c2ccccc2-c2ccccc2C1=O</smiles>

3<smiles>CC1(C)CN[C]c2ccccc21</smiles>

4<smiles>[R]c1n[se]c2ccccc2c1=O</smiles>

5
$\mathrm{R}=\mathrm{H}, \mathrm{CH}_{3}, \mathrm{CH}_{2} \mathrm{C}_{6} \mathrm{H}_{5}, \mathrm{C}_{6} \mathrm{H}_{5}$

$\mathrm{R}^{\prime}=\mathrm{H}, \mathrm{CH}_{3}$
$\mathrm{R}=\mathrm{H}, \mathrm{CH}_{3}, \mathrm{CH}_{2} \mathrm{C}_{6} \mathrm{H}_{5}, \mathrm{C}_{6} \mathrm{H}_{5}$

Scheme 2<smiles>N#Cc1ccccc1Cl</smiles>

6

\section{$\underset{\text { (2) Hydrolysis }}{\stackrel{\text { (1) } \mathrm{PhCH}_{2} \mathrm{CH}_{2} \mathrm{MgBr}}{\longrightarrow}}$}

(78\%)<smiles>O=C(CCc1ccccc1)c1ccccc1Cl</smiles>

7

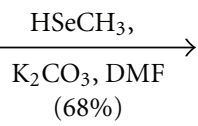

(68\%)<smiles>Cc1ccccc1C(=O)CCc1ccccc1</smiles>

8 $n-\mathrm{BuNO}_{2}, \mathrm{HCl}$ 2-ethoxyethanol (61\%)<smiles>O=c1c(Cc2ccccc2)n[se]c2ccccc12</smiles>

10

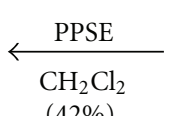

(42\%)<smiles>COc1ccccc1C(=O)/C(Cc1ccccc1)=N/O</smiles>

9

Scheme 3: The multistep synthesis of the novel $4 H$-benzo-1,2-selenazin-4-one 10.

${ }^{1} \mathrm{H}$ NMR $\left(400 \mathrm{MHz}, \mathrm{CDCl}_{3}\right): \delta_{\mathrm{H}} 2.21$ (s, 3H), $4.08(\mathrm{~s}, 2 \mathrm{H})$, 7.27-7.49 (m, 9H, ArH), $9.16(\mathrm{~s}, 1 \mathrm{H}),{ }^{13} \mathrm{C}$ NMR $(100 \mathrm{MHz}$, $\left.\mathrm{CDCl}_{3}\right): \delta_{\mathrm{C}} 7.3\left(\mathrm{CH}_{3}\right), 42.3\left(\mathrm{CH}_{2}\right), 124.6-148.2(\mathrm{C}$ arom $)$, $192.3(\mathrm{C}=\mathrm{O})$, LCMS: $m / z 334\left(\mathrm{M}^{+}\right)$.

4.3. Synthesis of 3-Benzyl-1,2-benzoselenazin-4-one (10). A suspension of phosphorus oxide $(7.05 \mathrm{mmol}, 2 \mathrm{~g})$ and hexamethyldisiloxane $(14.9 \mathrm{mmol}, 3.16 \mathrm{~mL})$ in dichloromethane $(15 \mathrm{~mL})$ was refluxed for till complete dissolution (45 min). The mixture was evaporated under reduced pressure to provide trimethylsilyl polyphosphate (PPSE) as a viscous liquid which was then added to a solution of oxime 9 $(0.69 \mathrm{mmol})$ in dichloromethane $(10 \mathrm{~mL})$. The mixture was refluxed under stirring for $8 \mathrm{~h}$, then cooled and washed with water $(2 \times 10 \mathrm{~mL})$ and dried over $\mathrm{MgSO}_{4}$. After evaporation of the solvent, the obtained residue was purified by column chromatography over silica gel using (tolueneacetone $75: 25)$ to provide heterocycle $\mathbf{1 0}$ as yellow solid, yield $42 \%$, Mp $139-142^{\circ} \mathrm{C}$, IR ( $\left.\mathrm{KBr}\right) \nu_{\max } 1668 \mathrm{~cm}^{-1}(\mathrm{C}=\mathrm{O})$, ${ }^{1} \mathrm{H} \mathrm{NMR}\left(400 \mathrm{MHz}, \mathrm{CDCl}_{3}\right): \delta_{\mathrm{H}} 4.04(\mathrm{~s}, 2 \mathrm{H}), 7.30-8.02(\mathrm{~m}$,
9H, ArH); ${ }^{13} \mathrm{C}$ NMR $\left(100 \mathrm{MHz}, \mathrm{CDCl}_{3}\right): \delta_{\mathrm{C}} 42.3\left(\mathrm{CH}_{2}\right)$, 127.2-153.2 (C arom), 193.2 (C=O), GCMS: $m / z$ of $>10 \%$ intensity $301\left(\mathrm{M}^{+}\right), 224,156$, Anal. Calcd for $\mathrm{C}_{15} \mathrm{H}_{11}$ NOSe: C, 60.01.; H, 3.69; N, 4.67, found C, 59.75; H, 3.73; N, 4.74.

4.4. Synthesis of 1-(2-(Methylselanyl)phenyl)-2-phenylethane1,2-dione (13). Compound $\mathbf{1 3}$ has been prepared from the diketone 12 according to the procedure described for compound 8. Brown solid, yield $60 \%, \mathrm{Mp} 115-119^{\circ} \mathrm{C}$; IR $(\mathrm{KBr}) \nu_{\max } 1671 \mathrm{~cm}^{-1}(\mathrm{C}=\mathrm{O}), 1650 \mathrm{~cm}^{-1}(\mathrm{C}=\mathrm{O}) ;{ }^{1} \mathrm{H}$ NMR $\left(400 \mathrm{MHz}, \mathrm{CDCl}_{3}\right): \delta_{\mathrm{H}} 2.30(\mathrm{~s}, 3 \mathrm{H}), 7.17-7.96(\mathrm{~m}, 9 \mathrm{H}, \mathrm{ArH})$; ${ }^{13} \mathrm{C}$ NMR $\left(100 \mathrm{MHz}, \mathrm{CDCl}_{3}\right): \delta_{\mathrm{C}} 7.3\left(\mathrm{CH}_{3}\right), 125.2-135.5$ (C arom), 194.6 and 195.6 (2 C=O); GCMS: $m / z$ of $>10 \%$ intensity $304\left(\mathrm{M}^{+}\right), 199,156$.

4.5. General Procedure for the Synthesis of Compounds 14 and 16. To a solution of compound $\mathbf{1 3}$ or $\mathbf{1 5}(1 \mathrm{mmol})$ in tetrachlorocarbon $(20 \mathrm{~mL})$, was added with stirring for a period of 30 minutes at $0^{\circ} \mathrm{C}$, a solution of bromine $(1.1 \mathrm{mmol})$ in tetrachlorocarbon $(20 \mathrm{~mL})$. The precipitate was refluxed 
<smiles>N#Cc1ccccc1Cl</smiles>

6

(1) $\mathrm{PhCH}_{2} \mathrm{MgBr}$

(2) Hydrolysis $(82 \%)$<smiles>CCc1ccccc1C(=O)Cc1ccccc1</smiles>

15

(1) $\mathrm{Br}_{2}$

(2)Heat

(3) $\mathrm{NH}_{3}(\mathrm{~g})$

$(52 \%)$<smiles>c1ccc(Cc2n[se]c3ccccc23)cc1</smiles>

$\frac{\mathrm{HSeCH}_{3},}{\mathrm{~K}_{2} \mathrm{CO}_{3}, \mathrm{DMF}}$

(60\%)<smiles>O=C(Cc1ccccc1)c1ccccc1Cl</smiles>

11<smiles>O=C(c1ccccc1)c1n[se]c2ccccc12</smiles>

$\underset{\mathrm{DMSO}}{\stackrel{\mathrm{SeO}_{2}}{\longrightarrow}}$

(61\%)<smiles>O=C(C(=O)c1ccccc1Cl)c1ccccc1</smiles>

12

$\mathrm{HSeCH}_{3}$,

$\mathrm{K}_{2} \mathrm{CO}_{3}$, DMF

$(60 \%)$

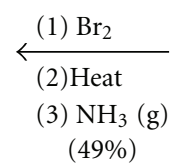

16

14

Scheme 4: The multistep synthesis of the novel benzisoselenazols 14 and $\mathbf{1 6 .}$<smiles>O=C(O)c1cccc([N+](=O)[O-])c1Br</smiles>

17
(1) $\mathrm{SOCl}_{2}$, pyridine

(2) $\mathrm{NH}_{2} \mathrm{NHPh}, \mathrm{Et}_{3} \mathrm{~N}$

18
$\underset{\mathrm{K}_{2} \mathrm{CO}_{3}, \mathrm{DMF}}{\stackrel{\mathrm{HSeCH}_{3},}{\longrightarrow}}$<smiles>COc1c(C(=O)NNc2ccccc2)cccc1[N+](=O)[O-]</smiles>

19 $\mathrm{Br}_{2}, \mathrm{Cl}_{2} \mathrm{CH}_{4}$<smiles>O=c1c2cccc([N+](=O)[O-])c2[se]n1Nc1ccc(Br)cc1Br</smiles>

Scheme 5: The multistep synthesis of the novel 2-(2,4-dibromophenylamino)-7-nitrobenzisoselenazol-3-one 20. 


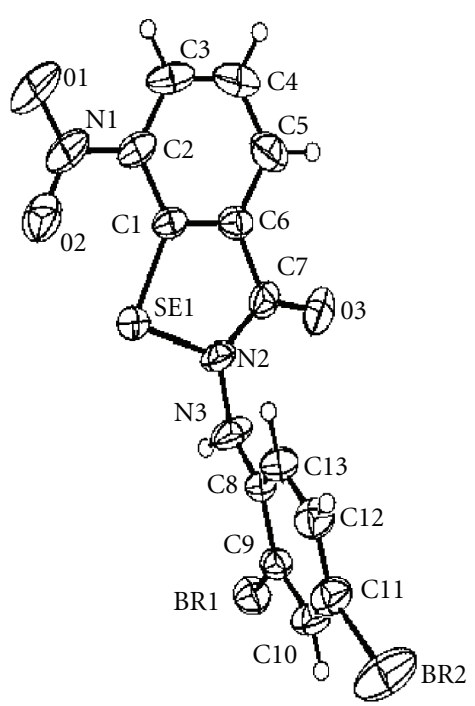

FIgURE 1: Crystal structure of compound 20.

in dichloromethane $(30 \mathrm{~mL})$ under stirring for $1 \mathrm{~h}$. After cooling, the mixture was saturated with a gaz ammonia flow. The insoluble substances were filtered and the solution was concentrated under reduced pressure. The obtained residue was purified by column chromatography over silica gel (toluene-acetone 95:5) to provide compounds 14 and 16.

1,2-Benzoselenazol-3-yl(phenyl)methanone (14). This compound was obtained as yellow solid, yield 49\%, Mp 75$79^{\circ} \mathrm{C}$, IR $(\mathrm{KBr}) v_{\max } 1660 \mathrm{~cm}^{-1}(\mathrm{C}=\mathrm{O}),{ }^{1} \mathrm{H}$ NMR $(400 \mathrm{MHz}$, $\left.\mathrm{CDCl}_{3}\right): \delta_{\mathrm{H}} 7.47-8.53(\mathrm{~m}, 9 \mathrm{H}) ;{ }^{13} \mathrm{C} \mathrm{NMR}(100 \mathrm{MHz}$, $\left.\mathrm{CDCl}_{3}\right): \delta_{\mathrm{C}} 123.1-145.5(\mathrm{C}$ arom), $197.8(\mathrm{C}=\mathrm{O})$; GCMS: $\mathrm{m} / z$ of $>10 \%$ intensity $287\left(\mathrm{M}^{+}\right), 259,282$; Anal. Calcd for $\mathrm{C}_{14} \mathrm{H}_{9}$ NOSe: C, 58.76.; H, 3.17; N, 4.89, found C, 58.87; H, $3.64 ; \mathrm{N}, 4.81$.

3-Benzyl-1,2-benzoselenazole (16). This compound was obtained as green oil; yield $52 \%$, IR $(\mathrm{NaCl}) v_{\max }$ absence of $(\mathrm{C}=\mathrm{O}),{ }^{1} \mathrm{H}$ NMR $\left(400 \mathrm{MHz}, \mathrm{CDCl}_{3}\right): \delta_{\mathrm{H}} 7.41-8.49(\mathrm{~m}, \mathrm{H}$ arom), ${ }^{13} \mathrm{C}$ NMR $\left(100 \mathrm{MHz}, \mathrm{CDCl}_{3}\right): \delta \mathrm{C} 127.0-137.7$ (C arom), GCMS: $m / z$ of $>10 \%$ intensity $273\left(\mathrm{M}^{+}\right), 193,164$; Anal. Calcd for $\mathrm{C}_{14} \mathrm{H}_{11} \mathrm{NSe}$ : C, 61.77.; $\mathrm{H}, 3.69 ; \mathrm{N}, 5.15$, found C, 61.86; H, 3.58; N, 4.08.

4.6. Synthesis of 2-(2,4-Dibromophenylamino)-7-nitrobenzisoselenazol-3-one (20). To a solution of hydrazide 19 $(1 \mathrm{mmol})$ in dichloroethane $(20 \mathrm{~mL})$, bromine $(3 \mathrm{mmol})$ was added with stirring for a period of $2 \mathrm{~h}$ at $0^{\circ} \mathrm{C}$. After evaporation of the solvent, the obtained residue was purified by column chromatography over silica gel using (toluene) to provide compound 20 as brown solid, yield 78\%, Mp 146$149^{\circ} \mathrm{C}$, IR (KBr) $\nu_{\max } 3269 \mathrm{~cm}^{-1}(\mathrm{NH}), 1671 \mathrm{~cm}^{-1}(\mathrm{C}=\mathrm{O})$, ${ }^{1} \mathrm{H}$ NMR $\left(400 \mathrm{MHz}, \mathrm{CDCl}_{3}\right): \delta_{\mathrm{H}} 4.19(\mathrm{~s}, 1 \mathrm{H}), 6.54-7.22$ (m, 5H), 8.21-8.56 (m, 3H); $\left.{ }^{13} \mathrm{C} \mathrm{NMR} \mathrm{(100} \mathrm{MHz,} \mathrm{CDCl}_{3}\right)$ : $\delta_{\mathrm{C}} 110.1-143.7$ (C arom), 167.3. $(\mathrm{C}=\mathrm{O})$; GCMS: $\mathrm{m} / z$ of
$>10 \%$ intensity 251, 170; Anal. Calcd for $\mathrm{C}_{13} \mathrm{H}_{7} \mathrm{Br}_{2} \mathrm{~N}_{3} \mathrm{O}_{3} \mathrm{Se}$ : C, 31.74.; H, 1.43; N, 8.54, found C, 31.93; H, 1.40; N, 8.47.

\section{Acknowledgment}

The authors gratefully acknowledge the financial support from Taibah University (Grant 428/158).

\section{References}

[1] J. T. Rotruck, A. L. Pope, H. E. Ganther, A. B. Swanson, and D. G. Hafeman, "Selenium: biochemical role as a component of glatathione peroxidase," Science, vol. 179, no. 4073, pp. 588$590,1973$.

[2] L. Flohë, W. A. Gunzler, and H. H. Schock, "Glutathione peroxidase: a selenoenzyme," FEBS Letters, vol. 32, no. 1, pp. 132-134, 1973.

[3] G. Mugesh, W. W. Du Mont, and H. Sies, "Chemistry of biologically important synthetic organoselenium compounds," Chemical Reviews, vol. 101, no. 7, pp. 2125-2179, 2001.

[4] G. Mugesh and H. B. Singh, "Synthetic organoselenium compounds as antioxidants: glutathione peroxidase activity," Chemical Society Reviews, vol. 29, no. 5, pp. 347-357, 2000.

[5] R. F. Burk, Ed., Selenium in Biology and Human Health, Springer, New York, NY, USA, 1994.

[6] L. Flohé, "The glutathione peroxidase reaction: molecular basis of the antioxidant function of selenium in mammals," Current topics in cellular regulation, vol. 27, pp. 473-478, 1985.

[7] A. L. Tappel, "Selenium-glutathione peroxidase: properties and synthesis," Current Topics in Cellular Regulation, vol. 24, pp. 87-97, 1984.

[8] O. Epp, R. Ladenstein, and A. Wendel, "The refined structure of the selenoenzyme glutathione peroxidase at $0.2 \mathrm{~nm}$ resolution," European Journal of Biochemistry, vol. 133, no. 1, pp. 5169, 1983.

[9] L. Flohë, G. Loschen, W. A. Gunzler, and E. Eichele, "Glutathione peroxidase, V. The kinetic mechanism," HoppeSeyler's Zeitschrift fur Physiologische Chemie, vol. 353, no. 6, pp. 987-999, 1972.

[10] M. J. Parnham and E. Graf, "Seleno-organic compounds and the therapy of hydroperoxide-linked pathological conditions," Biochemical Pharmacology, vol. 36, no. 19, pp. 3095-3102, 1987.

[11] M. Iwaoka and S. Tomoda, "First observation of a C-H...Se "hydrogen bond",' Journal of the American Chemical Society, vol. 116, no. 10, pp. 4463-4464, 1994.

[12] H. E. Ganther, "Selenoproteins," Chemica Scripta, vol. 8A, p. 79, 1975.

[13] H. E. Ganther, "Oxidation states of glutathione peroxidase," Methods in Enzymology, vol. 107, no. C, pp. 593-602, 1984.

[14] N. Dereu and E. Graf, "Ebselen," Drugs of the Future, vol. 9, no. 10, pp. 741-742, 1984.

[15] M. Parnham, S. Leyck, N. Dereu, J. Winkelmann, and E. Graf, "Ebselen (PZ 51): a GSH-peroxidase-like organoselenium compound with anti-inflammatory activity," Advances in Inflammation Research, vol. 10, pp. 397-400, 1985.

[16] R. Cantineau, G. Tihange, and A. Plenevaux, "Synthesis of ${ }^{75}$ Se-2-phenyl-1,2-benzisoselenazol-3(2H)-one (PZ 51; ebselen). A novel biologically active organo-selenium compound," Journal of Labelled Compounds and Radiopharmaceuticals, vol. 23, no. 1, pp. 59-65, 1986.

[17] A. Wendel, M. Fausel, H. Sarfadi, G. Tiegs, and R. Otter, "A novel biologically active seleno-organic compound. II. 
Activity of PZ 51 in relation to glutathione peroxidase," Biochemical Pharmacology, vol. 33, no. 20, pp. 3241-3245, 1984.

[18] M. J. Parnham and E. Graf, "Seleno-organic compounds and the therapy of hydroperoxide-linked pathological conditions," Biochemical Pharmacology, vol. 36, no. 19, pp. 3095-3102, 1987.

[19] V. Narayanaswami and H. Sies, "Antioxidant activity of ebselen and related selenoorganic compounds in microsomal lipid peroxidation," Free Radical Research Communications, vol. 10, no. 4-5, pp. 237-244, 1990.

[20] N. J. John, R. Terlinden, H. Fischer, M. Evers, and H. Sies, "Microsomal metabolism of 2-(methylseleno)benzanilide," Chemical Research in Toxicology, vol. 3, no. 3, pp. 199-203, 1990.

[21] M. C. Fong and C. H. Schiesser, "Reactions of 2,2'diselenobis( $\mathrm{N}$-alkylbenzamides) with peroxides: a free-radical synthesis of Ebselen and related analogues," Tetrahedron Letters, vol. 36, no. 40, pp. 7329-7332, 1995.

[22] H. Fischer and N. Dereu, "Mechanism of the catalytic reduction of hydroperoxides by Ebselen : a Selenium-77 Nmr Study," Bulletin des Sociétés Chimiques Belges, vol. 96, no. 10, pp. 757-768, 1987.

[23] R. S. Glass, F. Farooqui, M. Sabahi, and K. W. Ehler, "Formation of thiocarbonyl compounds in the reaction of Ebselen oxide with thiols," Journal of Organic Chemistry, vol. 54, no. 5, pp. 1092-1097, 1989.

[24] M. J. Parnham, J. Biedermann, C. Bittner, N. Dereu, S. Leyck, and H. Wetzig, "Structure-activity relationship of a series of anti-inflammatory benzisoselenazolones (BISAs)," Agents and Actions, vol. 27, no. 3-4, pp. 306-308, 1989.

[25] M. Renson and N. Dereu, "Benzisoselenazolinones and derivatives, a new series of antiinflammatory and antioxidant agents," Journal de Pharmacie de Belgique, vol. 45, no. 5, pp. 322-330, 1990.

[26] S. R. Wilson, P. A. Zucker, R. R. C. Huang, and A. Spector, "Development of synthetic compounds with glutathione peroxidase activity," Journal of the American Chemical Society, vol. 111, no. 15, pp. 5936-5939, 1989.

[27] H. J. Reich and C. P. Jasperse, "Organoselenium chemistry. Redox chemistry of selenocysteine model systems," Journal of the American Chemical Society, vol. 109, no. 18, pp. 5549-5551, 1987.

[28] P. V. Jacquemin, L. E. Christiaens, M. J. Renson, M. J. Evers, and N. Dereu, "Synthesis of 2H-3,4-dihydro-1,2-benzoselenazin-3-one and derivatives: a new heterocyclic ring system," Tetrahedron Letters, vol. 33, no. 27, pp. 3863-3866, 1992.

[29] A. Mohsine and L. Christiaens, "Synthesis of dibenzo[d,f]1,2-selena and -1,2-thiazepin-3-ones derivatives, bis-homoebselen," Heterocycles, vol. 43, no. 12, pp. 2567-2593, 1996.

[30] I. Erdelmeier, C. Tailhan-Lomont, and J.-C. Yadan, "Copper(I)-assisted mild and convenient synthesis of new Se-N heterocycles: access to a promising class of GPx mimics," Journal of Organic Chemistry, vol. 65, no. 24, pp. 8152-8157, 2000.

[31] M. Messali, L. E. Christiaens, S. F. Alshahateet, and F. Kooli, "Synthesis of 4H-benzo[e]-1,2-selanazin-4-one derivatives: a new heterocyclic ring system," Tetrahedron Letters, vol. 48, no. 42, pp. 7448-7451, 2007.

[32] G. Mugesh, A. Panda, H. B. Singh, N. S. Punekar, and R. J. Butcher, "Diferrocenyl diselenides: excellent thiol peroxidaselike antioxidants," Chemical Communications, no. 20, pp. 2227-2228, 1998.
[33] G. Mugesh, A. Panda, H. B. Singh, N. S. Punekar, and R. J. Butcher, "Glutathione peroxidase-like antioxidant activity of diaryl diselenides: a mechanistic study," Journal of the American Chemical Society, vol. 123, no. 5, pp. 839-850, 2001.

[34] T. Wirth, "Glutathione peroxidase-like activities of oxygencontaining diselenides," Molecules, vol. 3, no. 7, pp. 164-166, 1998.

[35] X. Zhang, H. Xu, Z. Dong, Y. Wang, J. Liu, and J. Shen, "Highly efficient dendrimer-based mimic of glutathione peroxidase," Journal of the American Chemical Society, vol. 126, no. 34, pp. 10556-10557, 2004.

[36] S. R. Wilson, P. A. Zucker, R.-R. C. Huang, and A. Spector, "Development of synthetic compounds with glutathione peroxidase activity," Journal of the American Chemical Society, vol. 111, no. 15, pp. 5936-5939, 1989.

[37] S. S. Zade, H. B. Singh, and R. J. Butcher, "The isolation and crystal structure of a cyclic selenenate ester derived from bis(2,6-diformyl-4-tert-butylpkenyl)diselenide and its glutathione peroxidase-like activity," Angewandte Chemie, vol. 43, no. 34, pp. 4513-4515, 2004.

[38] V. Galet, J.-L. Bernier, J. P. Hénichart et al., "Benzoselenazolinone derivatives designed to be glutathione peroxidase mimetics feature inhibition of cyclooxygenase/5-lipoxygenase pathways and anti-inflammatory activity," Journal of Medicinal Chemistry, vol. 37, no. 18, pp. 2903-2911, 1994.

[39] Y. You, K. Ahsan, and M. R. Detty, "Mechanistic studies of the tellurium(II)/tellurium(IV) redox cycle in thiol peroxidaselike reactions of diorganotellurides in methanol," Journal of the American Chemical Society, vol. 125, no. 16, pp. 4918-4927, 2003.

[40] T. Kanda, L. Engman, I. A. Cotgreave, and G. Powis, "Novel water-soluble diorganyl tellurides with thiol peroxidase and antioxidant activity," Journal of Organic Chemistry, vol. 64, no. 22, pp. 8161-8169, 1999.

[41] T. G. Back and Z. Moussa, "Remarkable activity of a novel cyclic seleninate ester as a glutathione peroxidase mimetic and its facile in situ generation from allyl 3-hydroxypropyl selenide," Journal of the American Chemical Society, vol. 124, no. 41, pp. 12104-12105, 2002.

[42] T. G. Back and Z. Moussa, "Diselenides and Allyl Selenides as Glutathione Peroxidase Mimetics. Remarkable Activity of Cyclic Seleninates Produced in Situ by the Oxidation of Allyl $\omega$-Hydroxyalkyl Selenides," Journal of the American Chemical Society, vol. 125, no. 44, pp. 13455-13460, 2003.

[43] T. G. Back, D. Kuzma, and M. Parvez, "Aromatic derivatives and tellurium analogues of cyclic seleninate esters and spirodioxyselenuranes that act as glutathione peroxidase mimetics," Journal of Organic Chemistry, vol. 70, no. 23, pp. 9230-9236, 2005.

[44] M. D. Drake, F. V. Bright, and M. R. Detty, "Dendrimeric organochalcogen catalysts for the activation of hydrogen peroxide: origins of the "dendrimer effect" with catalysts terminating in phenylseleno groups," Journal of the American Chemical Society, vol. 125, no. 41, pp. 12558-12566, 2003.

[45] S. Zhang and C. Zhang, "Discoveringcausality in large databases," Applied Artificial Intelligence, vol. 16, no. 5, pp. 333-358, 2002.

[46] M. McNaughton, L. Engman, A. Birmingham, G. Powis, and I. A. Cotgreave, "Cyclodextrin-derived diorganyl tellurides as glutathione peroxidase mimics and inhibitors of thioredoxin reductase and cancer cell growth," Journal of Medicinal Chemistry, vol. 47, no. 1, pp. 233-239, 2004. 
[47] A. Sudo and K. Saigo, "Design, synthesis, resolution, and application of a highly efficient chiral auxiliary: cis-2-amino3,3-dimethyl-1-indanol," Tetrahedron Asymmetry, vol. 7, no. 10, pp. 2939-2956, 1996.

[48] M. Yokoyama, S. Yoshida, and T. Imamoto, "Organic reactions ysing trimethylsilyl polyphosphate (PPSE): a convenient synthesis of nitriles from carboxamides," Synthesis, vol. 7, p. 591, 1982.

[49] L. Dupont, M. Messali, L. Christiaens, and G. Evrard, "2-(2,4Dibromophenylamino)-7-nitrobenzisoselenazol-3-one," Acta Crystallographica Section E, vol. E58, pp. o828-o830, 2002. 


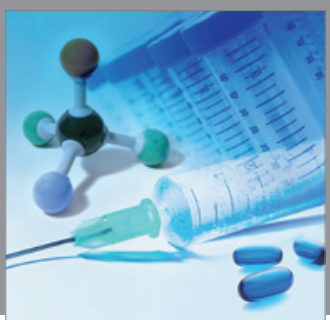

International Journal of

Medicinal Chemistry

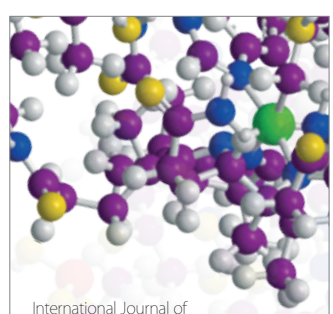

Carbohydrate Chemistry

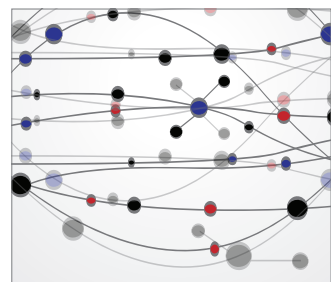

The Scientific World Journal
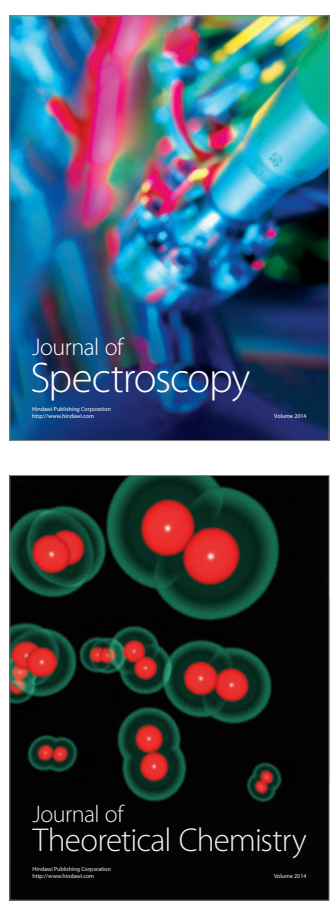
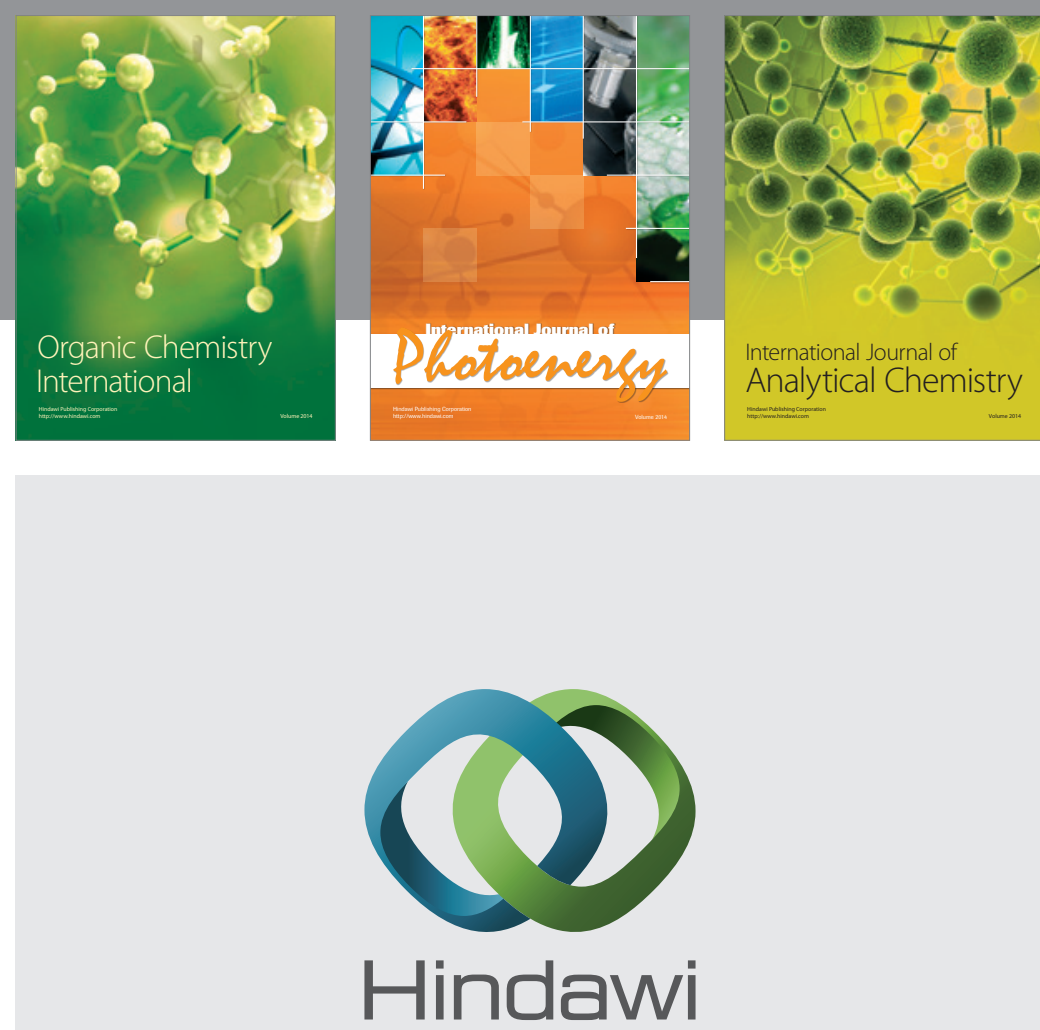

Submit your manuscripts at

http://www.hindawi.com
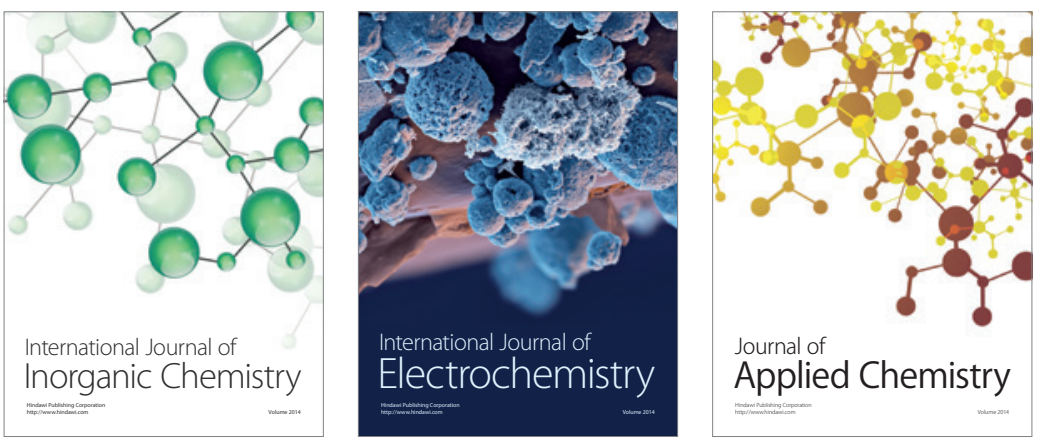

Journal of

Applied Chemistry
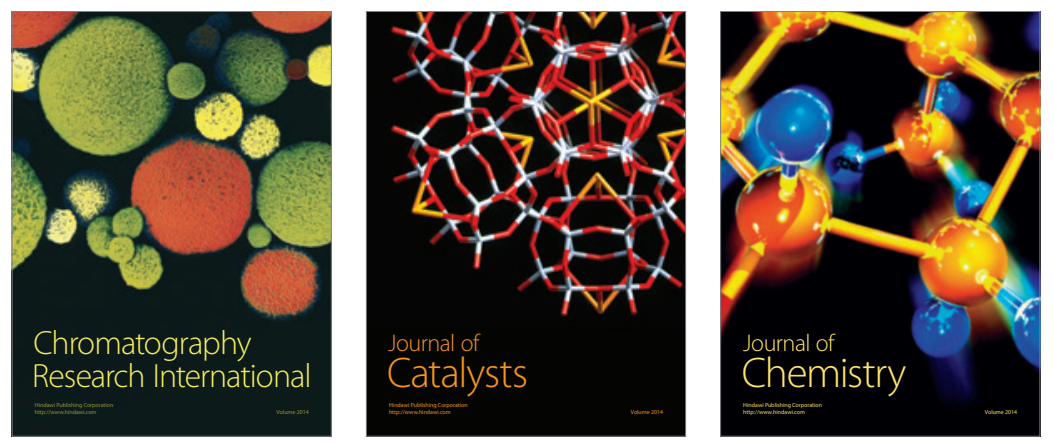
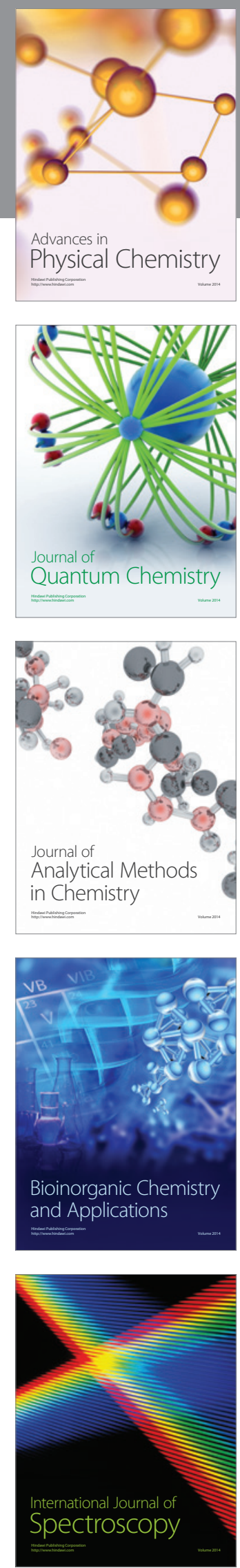